\title{
Schumpeter's Split Between "Pure" Economics and Institutional Economics: Why Methodological Individualism Was Not Fully Considered
}

\author{
Dieter Bögenhold ${ }^{1}$ (iD
}

Published online: 15 August 2018

(C) The Author(s) 2018

\begin{abstract}
While Joseph A. Schumpeter is classified as a pioneer of evolutionary economics in a wide sense and of entrepreneurship and innovation management in a narrower sense, Schumpeter is less known for his contributions in the area of scientific methodology and history of science. The paper deals with methodological premises in Schumpeter's scientific positioning. In 1908, in his Das Wesen und der Hauptinhalt der theoretischen Nationalökonomie, Schumpeter developed and pioneered his methodological individualism which is very much acknowledged. However, comparing these early positions with methodological writings in his History of Economic Analysis (1954) shows that he has not really shifted from methodological individualism to an institutional perspective that addresses the academic interplay and sees economic action rooted in historical predispositions, paths and social constraints.
\end{abstract}

Keywords Methodological individualism · Institutional economics · Joseph A. Schumpeter Economic methodology

JEL $\mathrm{B} 25 \cdot \mathrm{B} 30 \cdot \mathrm{B} 41 \cdot \mathrm{F} 14 \cdot \mathrm{F} 01 \cdot \mathrm{F} 20 \cdot \mathrm{O} 10$

\section{Introduction}

The paper deals with Joseph A. Schumpeter and his efforts to treat economics methodologically. Some authors argue that Schumpeter maintained his principal scientific

Dieter Bögenhold

Dieter.boegenhold@aau.at

1 Department of Sociology, Faculty of Economics, Alpen-Adria Universität Klagenfurt, 9020 Klagenfurt, Austria 
positions over the course of his life. ${ }^{1}$ It is said that he came up with his main ideas very early on in his European times and that he worked out those ideas more thoroughly during the following decades without changing his early positions very much. Compared to this view, one may see at least one clear shift in Schumpeter's principal positions between the early and late periods of his career. The paper discusses this shift, which is centered on Schumpeter's scientific positioning. In Das Wesen und der Hauptinhalt der theoretischen Nationalökonomie (1908), Schumpeter developed and pioneered his methodological individualism which is acknowledged. However, a comparison of these early positions with methodological writings in his History of Economic Analysis (1954) shows that he did not shift from methodological individualism to an institutional perspective that addresses the academic interplay and sees economic action rooted in historical predispositions, paths and social constraints. Both perspectives are related to each other. In our view, this clearly articulates a perspective of institutional economics that emphasizes social embeddedness of economic behavior.

Currently Schumpeter is viewed as a truly interdisciplinary theorist. He worked continuously in a perspective which can be characterized as academic cross-fertilization. Therefore, posthumously, Schumpeter's different articles were sorted into books as collected papers, political speeches, articles in socioeconomics, papers on economic policies, essays on daily politics, papers on economic theory, and articles on the history of economic thought (e.g. Schumpeter 1952, 1953). In a first instance, many contemporaries know primarily Schumpeter's ideas as they were developed in The Theory of Economic Development (Schumpeter 1963), perhaps also his book on Business Cycles (Schumpeter 1939) and, of course, his argumentation in Capitalism, Socialism, and Democracy (Schumpeter 1942), but lesser known is his systematization of academic development and his methodological roadmap.

The discussion focuses on the principles of Schumpeter's academic thought, which led him to create his diverse works and which were reflected systematically in some of his writings, from which Schumpeter emerged as a theorist of science. Besides working on specific substantial topics, throughout his life Schumpeter dealt with methodological issues in different works. He wrote articles on rationality, on positivism in economics, on mathematical methods in economic theorizing (Schumpeter 1906), How to Study Social Sciences (translated title) (Schumpeter 1915), Gustav von Schmoller und die Probleme von heute (Schumpeter 1926), and many more articles. Referring to books, his book Epochen der Dogmen- und Methodengeschichte (Schumpeter 1914, published in English as Economic Doctrines and Method in 1954), was certainly a major contribution to methodology in economics. Despite these many different works, I view Schumpeter's first book Das Wesen und der Hauptinhalt der theoretischen Nationalökonomie (Schumpeter 1908) and his last book History of Economic Analysis (Schumpeter 1954) as those studies are among his most diverse and show his latest and most up-to-date statements concerning the division of social sciences and the role of economics in relation to sociology, history, and other academic branches.

Das Wesen und der Hauptinhalt der theoretischen Nationalökonomie (Schumpeter 1908) was published when Schumpeter was only 25 years old. He wrote the book while

\footnotetext{
${ }^{1}$ For a discussion of Schumpeter within his times and in relation to his contemporaries, see Cantner and Dopfner (2015), also Michaelidis and Milios (2009, 2015).
} 
staying in Cairo, Egypt, before his career started in Vienna. History of Economic Analysis (Schumpeter 1954) was published four years after the death of Schumpeter, which was in 1950. The substantial preface of the History of Economic Analysis reads like a manual on how to refer to the different academic branches and how to integrate them into a coherent universal social science, which is far from being a narrow economic science of modern representation (Bögenhold 2014). Schumpeter must be regarded as someone who stayed on the solid ground of a well-studied history of mainstream economics which led him to argue offensively for an institutional approach integrating economics with different further social sciences by avoiding the formulation of a divisional order or ranking, which was already highlighted by Swedberg (1991).

Of course, Schumpeter's History of Economic Analysis has been extensively printed, translated and reprinted in several editions. However, especially the preface appears somewhat neglected in Schumpeterian discourse and his argumentation needs so much more text marking, because it must be read as a fine synthesis of arguments as developed in the first battles of methods between Carl Menger and Gustav von Schmoller and the second battle of methods between Schmoller and Max Weber and others (Shionoya 2005; Bögenhold 2008; Backhaus and Hansen 2000; Louzek 2011). In this sense, the old controversies were updated. In History of Economic Analysis (Schumpeter 1954), many questions were addressed in a more elegant and rigorous way. While Schumpeter is mostly regarded as a pioneer of evolutionary economics (Kurz 2012, 2015), who argued in favor of this perspective in The Theory of Economic Development (Schumpeter 1963), and especially in Capitalism, Socialism and Democracy (Schumpeter 1942), the last one containing the famous formulation of creative destruction (Fagerberg 2003), one may also view Schumpeter as an institutional economist who was searching for his methodological program.

\section{Methodological Individualism: An Undecided Term with Different Meanings}

There is still a controversial discussion regarding what methodological individualism really is and what it has meant. Udehn (2002) discussed the variety of different meanings of methodological individualism. He distinguished between softer and stricter variants of the program. Elster (1982) suggested that Marxism and game theory did not match with methodological individualism for different reasons. Urquhart (2013) discussed methodological individualism historically but always in specific relation to Marxism. Also, Vercelli (2016) discussed methodological individualism for contemporary economics in a negative light. Hodgson's (2007) explained methodological individualism and depicted the simple, but generally neglected, point that the meaning of the term has never been precisely stated and the idea is in fact ambiguous as to what it refers to (Davis 2016, p. 3). There are also further terms, such as micro and macro or agency and structure, which aim at similar problems and which link to the debate on methodological individualism. Somehow similar dichotomies become evident when comparing economics and sociology, since competing paradigms regarding the responsibility of the individual actor exist in both academic domains (Coleman 1990; Neck 2015). However, more generally one may conclude with Granovetter (2017) that the human agent in economics is conceptualized as a figure 
without any, or at least without many, social influences, while the human agent in sociology appears to be very much an effect of social influences. In consequence, Granovetter (1992) wrote that the actor in economics appears to be under-socialized and in sociology the actor is just the opposite, (s)he is over socialized.

Speaking for economics, Arrow (1994) explained the program of methodological individualism as an intellectual attempt to rationalize the workings of an economy and of economic procedures through the lenses of individual decisions.

"In the usual versions of economic theory, each individual makes decisions to consume different commodities, to work at one job or another, to choose production methods, to save, and to invest. In one way or another, these decisions interact to produce an outcome which determines the workings of the economy, the allocation of resources in short. It seems commonly to be assumed that the individual decisions then form a complete set of explanatory variables. A name is given to this point of view, that of methodological individualism, that is necessary to base all accounts of economic interaction on individual behaviour" (Arrow 1994, p. 1).

In other words, while economists necessarily have to agree that human beings are always in a social environment, they mostly "concentrated on the features of the individual in isolation" (Hodgson 2015, p. 56). This tradition goes back to Menger who tried to reduce the complex phenomena to the actions of individual actors. Especially in his Principles of Economics (Menger 1976, originally 1871), Menger tried to bring complicated matters of the economy to their simplest elements, these being the actions of individual human beings. Menger did not make use of the term methodological individualism but wrote about the atomistic method, which was meant to take the individual human agent as the starting point of analysis (Neck 2014). ${ }^{2}$ In some way, the perspective became central to Austrian economics. Hayek raised the issue that it is a marvel (Hayek 1945, p. 527), that economists take for granted what should be questioned, e.g. why do people do what they do. However, Hayek introduced the idea of a spontaneous order, which was characteristic of the price system at an aggregate level, which is an unintended result of individual decisions. "Its misfortune is the double one that it is not the product of human design and that the people guided by it usually do not know why they are made to do what they do" (Hayek 1945, p. 527). For Hayek, methodological individualism is always in conflict with evolutionary ideas (Lindemans 2012).

Joseph A. Schumpeter (1908) explicitly took up these questions when he discussed assumptions and consequences of methodological individualism. It was his first book (Schumpeter 1908) in which he orchestrated a broad discussion on the need to argue atomistically or to think in terms of social determinism. One 10-page chapter entitled The

\footnotetext{
${ }^{2}$ Reading Menger in light of new institutional economics (NIE), it looks as if a more direct line leads from NIE back to Schmoller, as the counterpart of Menger within the first battle of methods rather than to Menger. "Schmoller's critique of classical economics is strikingly similar to that made more recently by Ronald Coase the 'father' of the New Institutional Economics" (Furubotn and Richter 2005, 41). Schmoller insisted on the importance of comparative institutional analysis which is so central for current new institutional economics. "He considered such topics as evolution, feelings, and norms, as some modem institutional economists do" (Furubotn and Richter 2005, p. 42). However, reading new institutional economics as a discussion of organizational forms and efficiency (Williamson 1973, 1985) the recent level of discussion and terminological apparatus has become much more elaborated than the early discussion of Schmoller or Menger could do at their time (Ménard and Shirley 2008).
} 
Methodological Individualism (1908, part I, chapter 6) explained different concepts of human action. Among these concepts Schumpeter already used explicitly the term homo oeconomicus (Schumpeter 1908, p. 85) which was seen as a utility maximizer to be employed in "pure economics" (Schumpeter 1954). The homo oeconomicus was a semantic construct of hypothetical nature (Schumpeter 1908, p. 87). Lastly, Schumpeter did a meta-reflection regarding appropriate models to engage in economics. ${ }^{3}$

In order to clarify the semantics, Schumpeter distinguished between political and methodological individualism:

"Both concepts have nothing in common. The first refers to general statements like the freedom of people to develop themselves and to take part in well-being and to follow practical rules. The second does not include any proposition and does not involve a specific starting point. It just means that one starts from the individual in order to describe certain economic relationships" (Schumpeter 1908, pp. 90-91, translated by Heertje 2004, p. 153).

Later in History of Economic Analysis (Schumpeter 1954, p. 888), Schumpeter also introduced sociological individualism which referred to the self-governing individual that "constitutes the ultimate unit of the social sciences and that all social phenomena resolve themselves into decisions and actions of individuals that need not or cannot be further analyzed in terms of superindividual factors" (Schumpeter 1954, p. 888). Although Schumpeter already performed many charming advances in the direction of sociology (Schumpeter 1908, pp. 539-541) he did not go further at the end of his career to spell out forms of possible and reasonable cooperation and practical academic management (also Hodgson 2012, pp. 31-33).

Schumpeter's discussion on methodological individualism suggests that it was, in contrast to Menger's use of atomism, really undecided. Heertje (2004) was certainly right that methodological individualism

"conceals a double restriction. First, it is concerned with pure economics. Second, pure economics only refers to the analysis of flows of goods. This fact explains why the concept does not show up in other works by Schumpeter. One would expect the application of methodological individualism to the theory of economic development, innovation, bureaucracy and democracy, but these applications are outside the narrow framework that Schumpeter has chosen for this interpretation of methodological individualism" (Heertje 2004, p. 154).

Schumpeter's discussion oscillated permanently between a broad and a narrow interpretation of methodological individualism.

"While Schumpeter's broad view of economic and social relationships has contributed to insights into the role of entrepreneurs, innovators, bureaucrats, intellectuals and politicians, his narrow interpretation of methodological individualism, in fact, blocked the analysis of the rich pattern of individuals acting in real life" (Heertje 2004, p. 154).

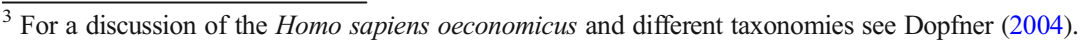


This observation has serious consequences since Schumpeter had an undecided split between methodological individualism as a heuristic principle towards pure theory on the one hand and an analysis of the institutional social and regulatory framework on the other hand. It seems that Schumpeter had difficulties deciding between a method, which analyzes the economy in abstracto on the one hand and in concreto on the other, in order to employ the semantic differentiation by Sombart (1982). ${ }^{4}$

\section{From Methodological Individualism to Institutional Economics}

Already in his very early writings Schumpeter (1908, part V) discussed the relationship of economics to sociology, biology, psychology, ethnology and ethics. However, in retrospect these biographically early discussions seem a bit unsystematic. Schumpeter orchestrated these areas much more broadly in his late work History of Economic Analysis (1954) where he reflected carefully about the division of different scientific branches. Schumpeter practiced an offensive dialogue with neighboring disciplines like sociology, history, political economy and psychology from the perspective of an economist. But even as an economist he discussed economics as practice and a field of professional activity. First of all, Schumpeter voiced a plea for working in the history of science.

Schumpeter argued not only in favor of economic history that renders a service to economic theory, but also in favor of "a sort of generalized or typified or stylized economic history" (Schumpeter 1954, p. 20) which includes institutions like private property or free contracting or government regulation; a sort of institutional economics which can be found (Kasper et al. 2012). In this way, economic institutionalism is a lens to look at the working of economies in their dependencies on historical paths, culture and governances (North 1990; Hodgson 1998). Of course, the ordo-institutional approach in the context of Austrian economics of earlier years (Kolev 2015) did not really acknowledge Schumpeter's split in theory concerns but almost referred, if at all, to Schumpeter and his conceptions of entrepreneurship. Thus, this form of institutionalism is not addressed here.

According to Schumpeter, there are four main reasons to study history. First of all, it has pedagogical advantages. He argues that, for the students, it is very difficult to approach a field without knowing how it is related to the specific historical time. For a thorough understanding, an historical background is required. One could affirm that the methods that are presently in use already embody what has been done in the past. What is not part thereof is no longer important and is not worth taking into consideration. However, our present methods and their results are meaningful only with reference to their historical background. "Scientific analysis is not simply a logically consistent process that starts with some primitive notions and then adds to the stock in a straightline fashion. It is not simply progressive discovery of an objective reality" (Schumpeter 1954, p. 4).

The second reason is that pertaining to the reading of old theories, one may discover other interpretations of them or new ideas. Schumpeter writes, that "our minds are apt

\footnotetext{
${ }^{4}$ For a discussion of similarities and divergences between Sombart and Schumpeter, see the article by Prisching (2015). 
to derive new inspirations from the study of the history of science" (Schumpeter 1954, pp. 4-5). In his discussion, Schumpeter adds an example: "The productivity of this experience may be illustrated by the fact that the fundamental ideas that eventually developed into the theory of (special) relativity occurred first in a book on the history of mechanics" (Schumpeter 1954, p. 5). The third cause is that history can give us insights into the ways in which the human mind works. Particularly in the history of science, various types of logic are used and scientific performances are self-revelatory by nature, that is, they reveal the mental processes that have taken place in order to arrive at a certain law or theory. "Scientific habits or rules of procedure are not merely to be judged by logical standards that exist independently of them; they contribute something to, and react back upon, the logical standards themselves" (Schumpeter 1954, p. 5). Finally, the fourth point deals with economics in particular, which is described as a unique historical process. Fundamentally this process does not differ from the analogous processes in other fields of knowledge but

"much more than in, say, physics is it true in economics that modern problems, methods, and results cannot be fully understood without some knowledge of how economists have come to reason as they do. In addition, much more than in physics has been lost on the way or remained in abeyance for centuries" (Schumpeter 1954, p. 6).

Schumpeter discussed several, from today's standpoint, independent scientific disciplines such as economic history, statistics, theory, economic sociology, political economy, and applied fields as techniques of economic analysis. In a subsequent chapter, he turned his attention to specific discussion topics such as the specific relationship between economics and sociology and between logic and psychology. Here, the reasoning is dense and much deeper than is usually assumed when coming across the conventional image of Schumpeter as a theorist of entrepreneurship. Instead, he engaged in a very precise sociology of science in which diverse matching processes between individual scientific areas and traditions of thought are investigated.

In discussing economic history, statistics, theory, economic sociology, political economy and applied fields as techniques of economic analysis, a clear conceptual ranking in terms of order is missing. Schumpeter understands each of them instrumentally and he regards the different elements taken together as a box of tools. Obviously, economics is a synonym for economic analysis, which operates through different academic configurations provided by the toolbox. The interplay of different branches comes up like an orchestra where different agents have different functions, but even the smallest voices contribute to the success of the common enterprise.

In contrast to the history of science as a history of changing intellectual ideas, Schumpeter referred to economic history, nomen est omen, as a history of economic and social changes. His plea for an integration of economic history in the orchestra of economic analysis reads this way:

"Nobody can hope to understand economic phenomena of any, including the present, epoch without an adequate command of historical facts and an adequate amount of historical sense, or of what may be described as historical experience. ... The historical report cannot be purely economic but must inevitably reflect 
also 'institutional' facts that are not purely economic: therefore, it affords the best method for understanding how economic and non-economic facts are related to one another and how various social sciences should be related to one another" (Schumpeter 1954, pp. 12-13).

According to Schumpeter, most of the ongoing errors in economic analysis are due to a lack of historical competencies, which leads him to acknowledge also the terrains of anthropology and ethnology:

"History must of course be understood to include fields that have acquired different names as a consequence of specialization, such as pre-historic reports and ethnology (anthropology)" (Schumpeter 1954, p. 13).

Regarding statistics, Schumpeter explained that we shall recognize that statistical methods are part of the tools of economic analysis because statistical figures or series of figures are of vital importance for economics (Schumpeter 1954, pp. 13-14). Consequently, "an adequate command of modern statistical methods is a necessary (but not a sufficient) condition for preventing the modern economist from producing nonsense" (Schumpeter 1954, p. 14).

When discussing theory, Schumpeter again did what could also be found in his earlier writings (such as Schumpeter 1926), which is that he writes the word theory with quotation marks. Schumpeter's intention was to explain that we have no precise commonly shared understanding of what we mean when talking about theory. In this respect Schumpeter proves to be a methodologist with profound knowledge of the philosophy of science. His set of questions includes: When does theory achieve the distinction of being "pure theory"? Why do we need studies in the history of economic thought? What about the intersections between theory, statistics, and economic history? Where are the borders and overlaps between economics, philosophy, psychology, political economy, and economic sociology? Which are general principles of scientific processes?

Schumpeter explains that theory has many meanings and it should not simply be interpreted as a semantic counterpart to practice. Schumpeter (1954, pp. 14-20) explains that three of these meanings are of special relevance: First, theory is an explanation of causal connections. Even if more of those causalities exist, one may summarize them taken together as theory. Second, theory is also a methodology at the level of paradigms, approaches and procedures which must be discussed academically. Here, we do not expect to find empirical results but methods to achieve scientific knowledge. Third, theory is reserved as a semantic of general economics (Schumpeter 1926 , p. 365 ff.). Viewing this discussion, a reader feels that many items remain provokingly up-to-date and finally unsolved. In the end, Schumpeter tries to find bridges between inductive and deductive procedures in order to arrive at a theory, which should provide an advanced holistic perspective. Already the fact that theory is written with quotation marks indicates Schumpeter's strength in perceiving and acknowledging the complexity of the matter. What is currently a topic in recent science theory was already problematized in Schumpeter's writings, namely that one should not take for granted the wording of theory since different types of theory and correspondingly different semantics coexist. The question of when an academic statement receives the status of being theory still remains on the agenda. 
It is not only economic history that renders a service to economic theory, as Schumpeter argues, but also economic sociology:

"Economic analysis deals with the questions how people behave at any time and what the economic effects are they produce by so behaving; economic sociology deals with the question how they came to behave as they do. If we define economic behavior widely enough so that it includes not only actions and motives and propensities but also the social institutions that are relevant to economic behavior such as government, property inheritance, contract, and so on, that phrase really tells us all we need" (Schumpeter 1954, p. 21).

There are several statements where Schumpeter speaks with great appreciation about economic sociology and claims that economics has to seek or to keep in closer contact with sociology because "we cannot afford ... to neglect the developments of sociology" and especially not the "fundamental field of economic sociology in which neither economists nor sociologists can get very far without treading on one another's toes" (Schumpeter 1954, pp. 25-26).

The following discussion of Schumpeter is concerned with logic, philosophy and psychology, which are not summarized under techniques of economic analysis but rather are discussed as a basic methodological understanding of his conceptual framework. Schumpeter explained in the introduction to that specific chapter that he uses nothing other than a philosophy of economics (Schumpeter 1954, p. 25) as a basic theoretical scientific reflection.

The most significant statement about economic psychology is contained in the following words: "Economics like other social sciences deals with human behavior. Psychology is really the basis from which any social science must start and in terms of which all fundamental explanation must run" (Schumpeter 1954, p. 27). Of course, Schumpeter is impressed by the argumentation of Keynes and Keynesianism of his time, which refers to animal spirits and other behavioral foundations. Also, this type of argumentation matches an idea which he presented in different theoretical discussion on methodological individualism much earlier (Schumpeter 1908).

His theory of science with a focus on economics in relation to different other academic areas, often historically new and emerging ones, must be viewed as a sociology of scientific ideas. Schumpeter explained this in his own words:

"From time to time, we shall look up from our work in order to view a piece of intellectual scenery. Slightly less perfunctorily, we shall, for every one of our periods, register some contemporaneous developments in other sciences ... that were relevant or might, for one reason or another, be expected to have been relevant to the development of our own" (Schumpeter 1954, p. 25).

\section{Conclusion}

The comparatively less cited preface of History of Economic Analysis (Schumpeter 1954) showed Schumpeter much more in light of a reflected institutional economist 
who treated history, sociology, psychology and further academic fields respectfully as common tools of scientific discovery. His often-quoted discussion of methodological individualism is less pronounced and in a narrow light is shown to be a meta discussion that Schumpeter did mainly with ideas provided by his predecessor and partly his contemporaries. His own position remains somehow vague in this respect. The oscillation between methodological individualism and institutional economics must be seen as a split that he did not really perceive as a split and with regard to which he did not really choose one side or another. As his late writings indicate, it looks very much like at the end of his academic life, Schumpeter was much more on the side of an interdisciplinary economist who acknowledged the social embeddedness of social behavior and institutions. When Schumpeter asks about the meaning of economic action, he discusses models of rationality. In general, all his theorizing is against practices of utilitarianism and against basic assumptions of economic theorizing. In other words, Schumpeter systematizes arguments in favor of an economics oriented towards real life as opposed to axiomatic assumptions of the nature of human beings. All his own applied economics in diverse areas reveal that he was not really governed by methodological individualism.

Acknowledgements Open access funding provided by University of Klagenfurt. Different versions of the paper were presented at the 3rd Cosmos + Taxis Conference on Studies in Emergent Order and Organization at the Bruno Leoni Institute, Milan, Italy, November 17-19, 2016, the 83rd International Atlantic Economic Conference, Berlin, Germany, March 22-25, 2017, and the 14th Annual STOREP Conference, Italian Association for the History of Political Economy, Università Cattolica del Sacro Cuore, Piacenza, Italy, June 810, 2017. The author is grateful for valuable comments given by David Andersson, Katia Caldari, Carlo Christiano, Reinhard Neck, Eugenio Somaini, anonymous reviewers, and participants of related discussions.

Open Access This article is distributed under the terms of the Creative Commons Attribution 4.0 International License (http://creativecommons.org/licenses/by/4.0/), which permits unrestricted use, distribution, and reproduction in any medium, provided you give appropriate credit to the original author(s) and the source, provide a link to the Creative Commons license, and indicate if changes were made.

\section{References}

Arrow, K. J. (1994). Methodological individualism and social knowledge. American Economic Review, 84(2), $1-9$.

Backhaus, J., \& Hansen, R. (2000). Methodenstreit in der Nationalökonomie. Journal for General Philosophy of Science, 31(2), 307-336.

Bögenhold, D. (2008). Economics, sociology, history: Notes on their loss of unity, their need for re-integration and the current relevance of the controversy between Carl Menger and Gustav von Schmoller. Forum for Social Economics, 37(2), 85-101.

Bögenhold, D. (2014). Schumpeter as a universal social theorist. Atlantic Economic Journal, 42(3), $205-215$.

Cantner, U., \& Dopfner, K. (2015). Schumpeter and his contemporaries. Journal of Evolutionary Economics, 25(1), 1-20.

Coleman, J. S. (1990). Foundations of social theory. Cambridge: Belkman Press.

Davis, J. B. (2016). Hodgson, cumulative causation, and reflexive economic agents (August 8, 2016). Institutions and the evolution of capitalism, essays in honour of Geoffrey M. Hodgson, Francesca Gagliardi and David Gindis, editors, Edward Elgar Publishing, Forthcoming. Available at SSRN: https://ssrn.com/abstract=2820226

Dopfner, K. (2004). The economic agent as rule maker and rule user: Homo Sapiens Oeconomicus. Journal of Evolutionary Economics, 14(2), 177-195. 
Elster, J. (1982). The case for methodological individualism. Theory and Society, 11(4), 453-482.

Fagerberg, J. (2003). Schumpeter and the revival of evolutionary economics: an appraisal of the literature. Journal of Evolutionary Economics, 13(2), 125-159.

Furubotn, E. G., \& Richter, R. (2005). Institutions and economic theory. The contribution of the new institutional economics. Ann Arbor: the University of Michigan Press.

Granovetter, M. S. (1992). Economic institutions as social constructions: a framework for analysis. Acta Sociologica, 35(1), 3-11.

Granovetter, M. S. (2017). Society and economy: framework and principles. Cambridge: The Beknap Press of Harvard University Press.

Hayek, F. v. (1945). The use of knowledge in society. American Economic Review, 39(4), 19-30.

Heertje, A. (2004). Schumpeter and methodological individualism. Journal of Evolutionary Economics, 14, $153-156$.

Hodgson, G. M. (1998). The approach of institutional economics. Journal of Economic Literature, 36(1), 166-192.

Hodgson, G. M. (2007). Meanings of methodological individualism. Journal of Economic Methodology, $14(2), 211-226$.

Hodgson, G. M. (2012). From pleasure machines to moral communities. An evolutionary economics without Homo Oeconomicus. Chicago: Chicago University Press.

Hodgson, G. M. (2015). Conceptualizing capitalism. Institutions, evolution, future. Chicago: Chicago University Press.

Kasper, W., Streit, M. E., \& Boettke, P. J. (2012). Institutional economics. Property, competition, policies. Cheltenham: Edward Elgar.

Kolev, S. (2015). Ordoliberalism and the Austrian school. In C. J. Coyne \& P. J. Boettke (Eds.), The Oxford handbook of Austrian economics (pp. 419-444). Oxford: Oxford University Press.

Kurz, H. (2012). Schumpeter's new combinations: Revisiting his Theorie der wirtschaftlichen Entwicklung on the occasion of its centenary. Journal of Evolutionary Economics, 22(5), 871-899.

Kurz, H. (2015). The beat of the economic heart: Joseph Schumpeter and Arthur Spiethoff on business cycles. Journal of Evolutionary Economics, 25(1), 147-162.

Lindemans, J. W. (2012). Methodological individualism and cultural evolution: ontogenetic and phylogenetic approaches to social order. Quarterly Journal of Economics, 15(3), 331-369.

Louzek, M. (2011). The battle of methods in economics. The classical Methodenstreit-Menger vs Schmoller. The American Journal of Economics and Sociology, 70(2), 439-463.

Ménard, C., \& Shirley, M. M. (2008). Introduction. Handbook of new institutional economics (pp. 1-20). Boston: Springer.

Menger, C. (1976 [1871]). Principles of economics. New York: NY University Press.

Michaelidis, P. G., \& Milios, J. G. (2009). Joseph Schumpeter and the German historical school. Cambridge Journal of Economics, 33(3), 495-516.

Michaelidis, P. G., \& Milios, J. G. (2015). The Schumpeter-Hilferding Nexus. Journal of Evolutionary Economics, 25(1), 133-146.

Neck, R. (2014). On Austrian economics and the economics of Carl Menger. Atlantic Economic Journal, 42(3), 217-227.

Neck, R. (2015). The positivist dispute after 50 years-an unrepentant 'positivist' view. Journal of Classical Sociology, 15(2), 185-190.

North, D. C. (1990). Institutions, institutional change and economic performance. Cambridge: Cambridge University Press.

Prisching, M. (2015). Understanding inescapable modernization: Werner Sombart and Joseph Schumpeter. Journal of Evolutionary Economics, 25(1), 185-196.

Schumpeter, J. A. (1906). Über die mathematische Methode der theoretischen Ökonomie. Zeitschrift für Volkswirtschaft, Sozialpolitik und Verwaltung, 15, 30-49.

Schumpeter, J. A. (1908). Das Wesen und der Hauptinhalt der theoretischen Nationalökonomie. Leipzig: Duncker and Humblot.

Schumpeter, J. A. (1914 [Engl. Transl. 1954]). Epochen der Dogmen- und Methodengeschichte. In K. Bücher, J.A. Schumpeter, F. v. Wieser (eds.). Grundriß der der Sozialökonomik, Vol. 1, Grundlagen der Wirtschaft, (pp. 19-124). Tübingen: J.C.B. Mohr.

Schumpeter, J. A. (1915). Wie studiert man Sozialwissenschaft? In Schriften des Sozialwissenschaftlichen Akademischen Vereins in Czernowitz (pp. 5-44). Munich: Duncker and Humblot.

Schumpeter, J. A. (1926). Gustav von Schmoller und die Probleme von heute. Schmollers Jahrbuch für Gesetzgebung, Verwaltung und Volkswirtschaft, 50, 337-388. 
Schumpeter, J. A. (1939). Business cycles: A theoretical, historical and statistical analysis of the capitalist process (Vol. 2). New York: McGraw Hill.

Schumpeter, J. A. (1942). Capitalism, socialism, and democracy. New York: Harper.

Schumpeter, J. A. (1952). Aufsätze zur ökonomischen Theorie. Tübingen: J.C.B. Mohr.

Schumpeter, J. A. (1953). Aufsätze zur Soziologie. Tübingen: J. C. B. Mohr.

Schumpeter, J. A. (1954). History of economic analysis. Oxford: Oxford University Press.

Schumpeter, J. A. (1963 [1912]). The theory of economic development. New York: Oxford University Press.

Shionoya, Y. (2005). The soul of the German historical school: Methodological essays on Schmoller, Weber and Schumpeter. New York: Springer.

Sombart, W. (1982 [1931]). Wirtschaft. In A. Vierkandt (Ed.), Handwörterbuch der Soziologie (pp. 209-216). Stuttgart: Enke.

Swedberg, R. (1991). The man and his work. In R. Swedberg (Ed.), Joseph A. Schumpeter. The economics and sociology of capitalism (pp. 3-98). Princeton: Princeton University Press.

Udehn, L. (2002). The changing face of methodological individualism. Annual Review of Sociology, 28, 479507.

Urquhart, R. (2013). Taking the modern for nature: methodological individualism as an interesting mistake. European Journal in the History of Economic Thought, 20(5), 812-844.

Vercelli, A. (2016). Microfoundations, methodological individualism and alternative economic visions. Review of Political Economy, 28(1), 153-167.

Williamson, O. E. (1973). Markets and hierarchies: some elementary considerations. The American Economic Review, 63(2), 316-325.

Williamson, O. E. (1985). The economic institutions of capitalism: Firms, markets, relational contracting. New York: Free Press. 